\title{
The Social Anxiety under Corona Virus Pandemic in Millennial Generation: an Experience of Indonesia
}

\author{
Deri Wanto \\ IAIN Curup, Rejang Lebong, Indonesia \\ deriwanto@iaincurup.ac.id \\ (Corresponding Author) \\ Jalwis \\ Institut Agama Islam Negeri (IAIN) Kerinci, Indonesia \\ jalwisiain3@gmail.com
}

\begin{abstract}
This study aimed at verifying the relationship between Covid-19 pandemic and social anxiety in the Millennial generation in Indonesia. The study used the OLS (Ordinary Least Squares) approach in analyzing the data from $44 \mathrm{I}$ respondents from 10 universities in Indonesia. The theory formulated as the finding of this study is: "The social anxiety experienced by the Millennials during the Covid-19 outbreak is a product of social situations. It is made a convincing case because there is a correlation between the Covid-19 pandemic in terms of the perceptions and understanding of the Millennial generation in Indonesia and social anxiety. The influence of the Covid-19 pandemic on social anxiety has even significantly folded." This article is useful to show how significant the influence of Pandemic Covid-19 on Social Anxiety in Millennials in Indonesia, where such studies have not even been adequately offered by other scholars. The study not only fills the gap but precisely becomes a preliminary study that measures the correlation of Covid-19 Pandemic to social anxiety in millennial generation in Indonesia.
\end{abstract}

Keywords: social anxiety, covid-19 pandemic, millennial generation, social anxiety disorder, psychological disorder.

Received 20 July 2021/Accepted 18 August 202I @Author all rights reserved

\section{Introduction}

The Covid-19 epidemic or corona virus disease has changed the social face in Indonesia. As a matter of fact, this change extends not only to the field of health but also to the fields of religion, economy and social (Reese et al., 2020). This is marked by changes in various aspects of social life (Ahmed et al., 
2020; Bal et al., 2020; Cai et al., 2020; Carmassi et al., 2020; Wind et al., 2020). In facing the Covid-19 epidemic, all religious, social, and governmental institutions have taken part in making policies (Xiang et al., 2020). The government made a policy in order that all governmental officials work from home. Meanwhile, the Indonesian Ulema Council issued a fatwa containing a ban on congregational prayer at the mosque for those in the red zone areas infected by Covid-19. However, such policies do not actually make people calm, but what happens is precisely the increasing social anxiety.

The cases of rejecting the corpses of patients infected by Corona Virus Disease have occurred in several places in Indonesia. For example, the body of a nurse, a 38-year-old woman, died at Dr. Kariadi Central Hospital in Semarang, was rejected when it was about to be buried. She died due to handling Covid-19 patients (Friana, 2020). This rejection occurred because of the community's anxiety over the corpse infected by Covid-19, and they were worried that if the body was buried close to the village area, it would adversely affect the residents' health. This rejection can be interpreted as a form of social anxiety (Kompas, 04/I7/2020). Social anxiety that arises in response to the Covid-19 Epidemic is inevitable (Dumas et al., 2020; Li et al., 2020; Mertens et al., 2020; Shiina et al., 2020). This happens considering that the number of cases of Covid-19 infection in Indonesia is increasing every day and is very worrying.

On April 20th, 2020, on the website page of the Task Force for Covid-19 handling in Indonesia, it was noted that the data of patients infected by Covid-19 were of 6,575 patients in total. 5,307 people were treated; 686 people were cured; and 582 people died. The mortality rate of Covid-19 patients in Indonesia is around 10.96\% (See Figure I). This means that the death rate in Indonesia is relatively high compared to other Southeast Asian countries. Covid-19 infection in Indonesia has spread to almost 34 provinces, and DKI Jakarta is the province with the highest number of cases, namely 3032 patients. Then, it is followed by West Java with 696 cases and East Java with 590 cases. Graphically, the total number of Covid-19 cases as of April 20th, 2020 in Indonesia can be displayed as follows: 


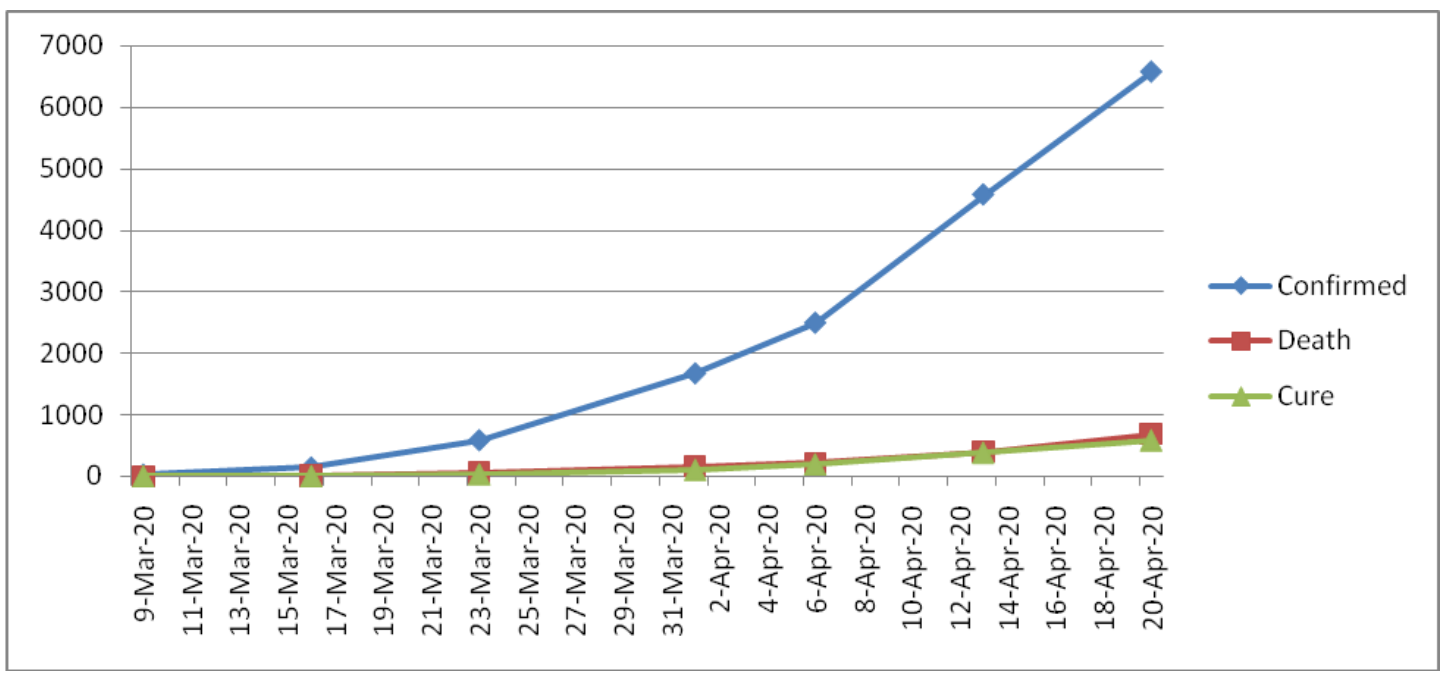

Source: www.kompas.com/covid-19, Accessed on April 20th, 2020

Figure I. National Trend of Covid-19 Infection in Indonesia

Understanding the national trend of the Covid-19 infection, it is reasonable if social anxiety arises and increases in the community. Millennials are one of the most vulnerable groups experiencing social anxiety, especially during the Covid-19 epidemic. This can be explained through Christopher A. Kearney's study, in which according to him, social anxiety can be identified from the presence or absence of social fears arising in a person and community groups. Such fears will impact on the deficit of social relations because individuals keep their distance from each other and refrain from social interactions (Kearney, 2005; Keliat et al., 2019). This social deficit occurs because of fears that threaten from both environment and oneself internally. It can generally be found during the Covid-19 epidemic, but the fears arise naturally because any human being is dealing with a deadly plague (Kumar \& Somani, 2020; Smith, 2013; Zhu et al., 2020). Although social anxiety can be experienced by those of all ages, however 'social fears' as part of social anxiety are generally often experienced by young people (Kearney, 2005). 


\section{Journal of Educational, Health and Community Psychology \\ Vol I0, No 3, 202I E-ISSN 2460-8467}

Wanto,

Jalwis.

Amid social change, crisis, and social uncertainty, social anxiety will increase in almost all circles, but it is more predominate in the circle of Millennial generation. This happens because Millennial generation is an age group with a critical phase of socio-emotional development (Leibenluft et al., 2020). They are faced with not only a level of mental instability but also the inability to conduct a complete social evaluation (Leibenluft et al., 2020; Situmorang, 2019). This condition makes the Millennial generation trapped in behavior that is different from general social behavior, for example, getting oneself locked down in a room or even limiting social association only to certain groups. Beside that, social anxiety at individual level during pandemic has elaborated through varied studies.

The existing literatures have focuses on the co-factor that stimulates the social anxiety. There are a set of factors frequently effecting the social anxiety during the Covid-19 pandemic has been identified by scholars i.e., psychological problems, lockdown policy over countries, change learning method and social distancing (Islam et al., 2020; Sundarasen et al., 2020; Syahir, 2020). It can be understood, there is a lack literatures that specifically elaborate how Covid-19 pandemics stimulated the social anxiety among millennial generation. In this regard, the article effort to fill the gap through a research question-did the covid-19 pandemic effects the social anxiety among millinneal generation In Indonesia.

In addition, social anxiety can be seen from feeling uneasy, an excessive fear of the presence of others. This feeling then coexists with verbal actions and behavior that evaluate the presence of others (Karasewich \& Kuhlmeier, 2020). Grounded in this study, social anxiety is very likely to even occur during the Covid-19 epidemic, but what kind of social anxiety is experienced by Millennial generation in Indonesia? What is the relationship between Covid-19 pandemic and social anxiety amid the Millennial generation in Indonesia? To provide answers to those questions, this study is aimed at identifying the relationship of the Covid-19 pandemic and social anxiety amid the Millennial generation in Indonesia. In addition, it is also intended to find out what kinds of social anxiety are generally experienced by the Millennial generation in Indonesia. 


\section{Literature Review}

To understand the two variables proposed in this study, namely pandemic Covid-19, more specific to the perception of Covid-19, and social anxiety, it is worth exploring some concept constructs and the framework for understanding these two things. Theoretically, there are many studies related to social anxiety, and they have been contained in some literature, especially scientific journals. Nonetheless, one related to the perception of Covid-19 is a relatively new variable, so the literature that reveals that concept is very limited. In this section, it is necessary to decipher several concepts that are theoretically useful for constructing the study constructs. They extend to: First, the development of the nature and characteristics of social anxiety, and Second, perception as a variable.

The social anxiety is something complex. It is not merely described as an excessive fear when dealing with others, but it is also marked by a sense that is not easy, severity, and the fear of interacting and doing actualization (Karasewich \& Kuhlmeier, 2020; S. G. Hoffman, 2010). Such a fear just arises because it is driven by many factors such as trauma, feeling incompetent, or the existence of a threat to personal safety. In addition, social anxiety is not something independent. It is a social product, where anxiety is also driven by negative social views or evaluations attached to a person, the sufferer of social anxiety (Arkin, R. M., Appelman, A. J., \& Burger, 1980; Elsantil \& Hamza, 2019; Han et al., 2019; Karasewich \& Kuhlmeier, 2020). This feeling can last for a long time depending on what kind of stimulus a person is facing, and the stimulus creates anxiety in a person (Leary, M. R., \& Kowalski, 1995). This interpretation implicitly links social anxiety to negative evaluations that are socially produced (Kearney, 2005). These evaluations encourage someone to have social avoidance.

Nevertheless, the meaning of social anxiety has expanded. It is not only limited to negative evaluations but also driven by a social panic situation caused by both chaos, economic crisis, politics, and even a pandemic (Dubey et al., 2020; Liu et al., 2020; Olapegba et al., 2020; Oosterhoff et al., 2020). In this situation, social anxiety arises as an "exposure to the feared social situation", or is exposed to social fears because of the situation (Kearney, 2005). This concept connects social anxiety with social panic, where both can bring up fears from bad social situations (Buss, 2005). In this characteristic, social anxiety can 
be experienced by everyone on a broad scale (Buss, 2005; Gilbert, 200I). This concept is one proof of the development of the meaning and scope of social anxiety.

Initially, social anxiety is identified and grouped into one type of psychological disorder, but the concept is further developing. At present social anxiety is generally believed that it can emerge as a product of social situations (Buss, 2005). Therefore, social anxiety at the time of the Covid-19 pandemic is relevant in this context. Empirically, social anxiety as a product of panic situations is different from social anxiety as a form of psychological disorder. The differences can be traced through the characteristics of these two forms of social anxiety.

Social anxiety in psychological studies is often interpreted to be the same as shyness, introversion, or social anxiety disorder (Hezel, \& McNally, 20I4; Hoffman, 2010). Nevertheless, social anxiety certainly differs quantitatively in terms of the levels and determinant factors of the anxiety triggers. McNeil even identified that social anxiety is also triggered by genetic and biological factors (McNeil, Porter, Zvolensky, Chaney, \& Kee, 2000). In the most common form, anxiety can be interpreted as a mood condition characterized by negative effects and symptoms of physical tension where a person anticipates the possibility of danger or misfortune in the future with feelings of worry (Barlow, H.D., \& Durand, 1995). From this concept, social anxiety can be interpreted as anxiety in terms socialization or other groups (Lestari, 2012). This concept also serves as the foundation for formulating the characteristics of social anxiety, namely: First, social anxiety is related to the fears experienced by individuals when carrying out social interactions with other people and groups.

Second, social anxiety arises related to several things such as anxiety about the future, personal safety, and the emergence of feelings of being negatively evaluated by other people and groups. In relation to adolescents, social anxiety that arises will encourage diverse reactions such as withdrawal and feeling tense when in a particular social environment (Lestari, 20I2). The feelings experienced by adolescents when experiencing social anxiety are the increase of sensitivity, feeling rejected, feeling unhappy, and lacking confidence (Lestari, 2012). The foregoing is found in social anxiety triggered by panic from a bad situation, for example in the middle of the Covid-19 pandemic. Generally, during the Covid-19 


\section{Journal of Educational, Health and Community Psychology \\ Vol I0, No 3, 202I E-ISSN 2460-8467}

Wanto,

Jalwis.

pandemic, people including the Millennials are experiencing social anxiety. This is certainly detrimental to the future's life of the Millennial generation if the covid-19 pandemic lasts long because theoretically Millennials who continue to experience social anxiety will result in a bad future for themselves ( Hoffman, 2010).

If social anxiety as a psychological disorder is marked by the emergence of excessive caution and psychological discomfort when interacting with others (Crozier \& Alden, 2005; Sergeeva et al., 2019), the same thing was also found during the Covid-19 pandemic in many circles, including the Millennial generation. Empirically, the Covid-19 pandemic has been a trigger for an increase in mental health disorders. Some studies show that Covid-19 has an impact on the mental state of society (Patrick Galey, 2020). The most common thing experienced by people in the midst of the Covid-I 9 pandemic is the increase of fear (Patrick Galey, 2020). This fear then drives an attitude of caution, self-care excessive. In this situation, social interaction will worsen with increasing social anxiety.

\section{Covid-1 9 Pandemic and its Relation to Social Anxiety}

World Health Organization officially stipulates Covid-19 as a global pandemic. The determination was made in light of that Covid-19 is an infectious disease that spreads easily from human to human and occurs in various places throughout the world (Friana, 2020). Corona Virus Disease becomes a pandemic not only caused by this virus alone, but also driven by social problems, for example, low community's immunity due to poor economic and social factors (Hamdan Mansour et al., 2020; Singh et al., 2020). Covid-19 infects people with low immunity and will trigger mass infections that are difficult to avoid and overcome. So, Covid-19 is not just a health problem. There are social and economic problems accompanying it. As a simple illustration, when the Covid-19 pandemic outbreaks, social anxiety will increase (Abdullah, 2020; Tian et al., 2020; Varalakshmi \& Swetha, 2020). This reduces the frequency of interaction among community members. As a result, the quality of social and even economic capital will decline. In this situation, social anxiety then increases in the community. Simply put, the Covid-19 pandemic not only makes people bad but also encourages social anxiety. 
The relationship between a pandemic and social anxiety can be explained through some literature. Betty Pfefferbaum and Carol S. North (2020) stated that the pandemic triggered the vulnerability of some social groups to experience psycho-social disorders, for example excessive social anxiety. Included in these groups are parents, social groups that have impaired immunity, and even Millennial generation that basically has socially active characteristics. This condition can be understood because anyone and people from any social group, when the surrounding environment experiences drastic changes and is full of uncertainty, then the community will experience feelings of anxiety and insecurity (Mehrollahia et al., 2019; Mohamad et al., 2019; Usher et al., 2020). Pandemic is one of the triggers of uncertainty and significant changes in the social, economic, and cultural environments. Responding to these changes, people and individuals tend to be trapped in negative social behavior (Rubin, G. J. \& Wessely, 2020; Usher et al., 2020). Negative social behavior can be manifested in many forms, ranging from protecting yourself from social interactions to phobias in the presence of others.

Pandemic has triggered the presence of fear in the people themselves. The Covid-19 pandemic has shown this. The fear caused by the Covid-19 pandemic triggers the community to take preventive action to the maximum. Washing hands; wearing a mask; avoiding the crowd; staying at home; not even coming to the place of worship are the people's behavior and response to covid-19. This fear can be interpreted as a response in breaking the chain of infection, and individuals have specific ways to protect themselves from the infection. Medically, hyper vigilance can increase with excessive anxiety and fear (Perrin, P. C., McCabe, O. L., Everly, G. S. \& Links, 2009; Usher et al., 2020).

The relationship between the Covid-19 pandemic and social anxiety can be tested empirically. In this context, this study was conducted to carry out empirical scrutiny on what kind is the relationship between the Covid-19 pandemic and social anxiety, which is more specific to the Millennial generation in Indonesia. In addition, this study identifies the form of the dominant social anxiety experienced by Millennial generation in Indonesia. For this reason, it needs specific research strategies and approach, an approach that can measure and at the same time be able to correctly identify the objectives of the study. Therefore, a quantitative way is chosen as a method and is applied as a whole in this study. 


\section{Method}

\section{Participants}

The choice of research participants is based on ethics and informed consent subject, where the choice is based on several considerations such as: I) Prospective participants are informed (informed) so that they understand their involvement as a subject; (2) Prospective participants provide consent which includes an explicit statement that he understands and agrees to participate in the research; and (3) the personal decision to get involved is something that is voluntary, without physical pressure (violence, physical coercion) or psychological pressure, i.e., manipulation or lying (Ferreira \& Serpa, 2018; Musmade et al., 2013). The participants engaged in this study were 44I (four hundred and forty one) respondents, who voluntarily filled out the questionnaires distributed online. However, in the data analysis input, the respondents were divided into two categories: the respondents displayed with the maximum number, namely $44 \mathrm{I}$ respondents; and those displayed with the minimum number, as many as 133 respondents. The data collection was designed using Google Docs, and it was believed to be able to reach many Millennials in Indonesia. This was also the merit that online questionnaires could reach Millennials from various cultural backgrounds (Gaiser \& Schreiner, 20I2). The 44I participants came from several campuses in Sumatra and Java. This way enabled to engage respondents from different cultural perspectives in addressing the relationship between the Covid-19 pandemic and the social anxiety faced.

Table I

Respondents' Universities

\begin{tabular}{cll}
\hline I. & IAIN Curup & Bengkulu, Rejang Lebong \\
2. & IAIN Bengkulu & Bengkulu \\
3. & UIN Raden Fatah & South Sumatra, Palembang \\
4. & Sriwijaya University & South Sumatra, Palembang \\
4. & IAIN Sheikh Abdurrahman Siddik & Bangka Belitung \\
5. & UIN Raden Intan & Lampung \\
6. & UIN Imam Bonjol & West Sumatra, Padang \\
7. & IAIN Bukittinggi & West Sumatra, Bukittinggi \\
8. & Ar-RaniryUIN & Aceh \\
9. & UIN Syarif Hidayatullah & Jakarta \\
10. & Baiturrahmah University & West Sumatra, Padang \\
\hline
\end{tabular}


The voluntary data collection involved 10 (ten) universities in 7 (seven) Provinces in Indonesia, where they consisted of 8 (eight) Islamic Universities and 2 (two) public universities, namely Sriwijaya University in Palembang and Baiturrahmah University in West Sumatra. In terms of gender, respondents who voluntarily filled out online questionnaires were dominated by women with the percentage of $74.5 \%$, whereas, men with the percentage of $25.5 \%$. From the aspect of ethnicity, the respondents were more diverse, with fairly high heterogeneity, starting out from Java, Sundanese, Rejang, Minang, Lampung, Mandailing, Aceh, Lembak, Semende, Alas, Balaimansiang, Malay, Betawi, Panai, Bugis, Komering, to Pak Pak. Likewise with the ages of respondents that were heterogeneous although the more dominant ones were the respondents with the age of 19 years oled, and at least 24 years old.

Table 2

Ages of Respondents (n: 44I)

\begin{tabular}{ll}
\hline Age: & Freq:\% \\
18 & $20(4.6)$ \\
18.5 & $6(1.4)$ \\
19 & $93(21.2)$ \\
19.5 & $38(8.7)$ \\
20 & $89(20.3)$ \\
20.5 & $22(5)$ \\
21 & $76(17.3)$ \\
21.5 & $18(4.1)$ \\
22 & $40(9.1)$ \\
22.5 & $10(2)$ \\
23 & $10(2.3)$ \\
23.5 & $5(1.1)$ \\
24 & $4(0.9)$ \\
\hline
\end{tabular}




\section{Measures}

Covid-19 Pandemic Scale (CPS) is a scale that aims to measure social perception of Covid-19. There are a set of items as used-scale. It has been classified into several variable groups. The first group is item for subject information i.e., name, age, gender and etnics. Second group is for identification of social anxiety during Covid-19 pandemic. For example, "in your opinion, does the COVID-19 outbreak cause anxiety?". Third items is classified as perception toward pandemics i.e., Covid-19 is easily contagious, but people with strong immunity can survive. The last classification of item is on social anxiety related to Covid- I 9 i.e, Out of concern, I reluctantly shook hands with other people. Using the likert scale, this study measured perceptions based on grades I-4. The grade I was given to the judgmental perception categorized into "strongly disagree". The grade 2 was given to the judgmental perception classified into "disagree”. The grade 3 represented the judgmental perception categorized into "agree". Subsequently, the grade 4 represented the judgmental perception classified into "strongly agree” (Han et al., 2019). This scale measured respondents' perception and understanding of Covid-19 (e.g. the perception of Covid-19 extends to how they understand Covid-19 in terms of its conception and preventions). While, the scale for measuring social anxiety (e.g. worrying about exposure to Covid-19; making respondents no longer order services online) also used a scale of I-4 with the levels of measurement: never, rarely, often, and always. This scale was used to measure how high is the frequency of social anxiety experienced during the Covid-19 pandemic (Carleton, R. N., Collimore, K. C., McCabe, R. E., \& Antony, 20II).

Specifically on the scale of measuring social anxiety, the question items were constructed on the basis of how consistent those items could be used to multiply the experiences of respondents or the social anxiety experienced by them (Han et al., 2019). Question items in the questionnaire were used and distributed after the validity and reliability tests were carried out. For the validity test, the statement items for measuring the perception scale of Covid-19 had the value of Pearson correlation as high as 0.635 for the minimum value and 0.777 for the maximum value. This means that the items on the questionnaire could be declared valid for collecting data. Subsequently, pertinent to the instrument reliability value, the Cronbach's alpha value of the instrument was 0.793 . Thus, this value indicated the fulfillment of the reliability principle (Nunnally, 1960). In addition, as a prerequisite for simple linear 
regression analysis, a normality test is needed, where the residuals of the independent and dependent variables are normally distributed (Shalit, 20I2). In the meantime, the linearity test serves to determine whether the relationship between independent and dependent variables is linear (Panagiotidis, 20I4). The two tests (e.g. normality and linearity) can be informed as follows:

Table 3.

Normality and Linearity

\begin{tabular}{lll}
\hline Kolmogorov-Smirnov One-Sample Test & Unstandardized Residual \\
\hline Normal Parameter $^{\mathrm{a}}$ & Mean & .0000000 \\
& Std. Deviation & 3.44507294 \\
Kolmogorov-Smirnov Z. & & 597 \\
Asymp.Sig. (2-tailed). & & 869 \\
\hline
\end{tabular}

${ }^{a}$ Test distribution is normal

\begin{tabular}{lllll}
\hline & & & Sum of Square & Sig. \\
\hline Social Anxiety & Between Group & (Combined) & 934731 & .630 \\
19Covid pandemics & & Linearity & 158,155 & .358 \\
& & Deviation from Linearity & 776,576 & .652 \\
& Within Group & & 588500 & \\
& Total & & 1523.231 & \\
\hline
\end{tabular}

Statistical information from normality and linearity tests indicated that: First, referring to the statistical rules if the significance value is $>0.05$, then the residual value is normally distributed. Therefore, it could be concluded that the residuals on the independent and dependent variables of this study were normally distributed. Second, the relationship between the $X$ variable (independent) and the $Y$ variable (dependent) can be called linear if the value of sig. deviation from linearity is $>0.05$. Then, it could be concluded from the statistical information presented in table 3 that the relationships between variables in this study were linear because the value of sig. deviation from linearity was $0.652>0.05$. From these normality and linearity tests, the hypothesis testing can be performed on two variables, namely Covid19 pandemic and social anxiety. 


\section{Statistical Analysis}

The data of this study were presented in the form of means for numerical variables and numbers and percentages for nominal variables. In addition, the relationship between the Covid-19 pandemic (e.g. perception and understanding of Covid-19) and social anxiety was analyzed through simple linear regression (Han et al., 2019), with the independent variable referring to the Covid-19 pandemic and the dependent variable represented by social anxiety. This simple linear analysis was based on OLS (Ordinary Least Squares). This analysis technique was chosen because conceptually this approach is interpreted as: "the line that mathematically bisects the OLS YX and the OLS XY lines (Saraçlı et al., 2009; Saylor, R.D., Edgerton, E.S. and Hartsell, 2006). Simply put, by the determination of the OLS technique, the relationship between the variables $X$ and $Y$ can be calculated better, and is able to minimize measurement errors on the variables used (Saraçlı et al., 2009). Thus, the statistical analysis techniques used (e.g. standard deviation, means, and OLS techniques) were believed to be able to provide a picture of the relationship between the Covid-19 pandemic and social anxiety in the Millennial generation in Indonesia.

\section{Results}

The behavior of Millennial generation in Indonesia in responding to the Covid-19 pandemic was certainly determined from how they defined and understood the Covid-19 itself. Not only that, the meaning of the situation they faced also determined how they acted and behaved towards Covid- 19 . When Covid-19 became epidemic, Millennial generation's understanding of the situation could be categorized into several meanings: First, they understand that this situation is very serious and should not be underestimated. Second, Indonesia is facing an emergency situation. Third, some understand that this is not a threat but only made exaggerated. 
Table 4

Covid-19 Pandemic in Millennial Generation's Perceptions

\begin{tabular}{llll}
\hline Defining Situation: $\quad$ n: 439 & \multicolumn{3}{c}{ Causing Anxiety } \\
\hline The situation is very serious, it should not be & 392 & Yes & $429(97.7)$ \\
underestimated & $(89.3)$ & & \\
Emergency situation & $36(8.2)$ & No & $10(2.3))$ \\
Not a threat, just over exaggeration & $11(2.5)$ & & \\
\hline
\end{tabular}

Millennials in Indonesia defined the situation related to the pandemic of corona virus in almost homogeneous ways. As the foregoing, they predominantly defined that the situation faced by Indonesia when Covid-19 became a pandemic was very serious and should not be underestimated. This was proven by 392 respondents (89.3\%) acknowledging this. There were only II respondents or $2.5 \%$ of them who defined this situation as harmless, or simply made exaggerated. As a consequence of this trend, 429 respondents or around $\mathbf{9 7 . 7 \%}$ of them admitted that this situation had caused social anxiety. There were only $2.3 \%$ of the respondents who admitted the opposite. These data become the foundation for identifying the forms of anxiety experienced by the Millennial generation in Indonesia.

In order to identify the forms of anxiety experienced by the Millennial generation, some of the most common forms of anxiety experienced by the Millennial generation in Indonesia were formulated, namely: First, anxiety when hearing information about Covid-19; Second, worry about going out of the house; Third, worry if being in crowded places (e.g. markets and places of worship); Fourth, anxious about leaving home without wearing a mask; and fifth, worry when shaking hands with others. These 5 (five) forms of anxiety actually referred to the psychological implications of the Covid-19 pandemic to the Millennial generation in Indonesia. The aforementioned forms of anxiety encouraged them to be very careful in their social interactions. 
Table 5

Covid-19 Pandemic and the Forms of Anxiety arisen

\begin{tabular}{lc}
\hline Form of Anxiety & $\mathrm{n}: 438$ \\
\hline Worry when hearing Covid-19 Information & $98(22.4)$ \\
Anxiety about Traveling outside the house & $137(31.3)$ \\
Worry in Crowded-places (e.g. market and place of worship) & $138(31.5)$ \\
anxious about leaving home without wearing a mask & $28(6.4)$ \\
Worry when shaking hands with others & $37(8.4)$ \\
\hline
\end{tabular}

Feeling anxious when being in crowded places, such as a market or a place of worship, became the most common anxiety felt by Millennial generation in Indonesia. There were 138 (one hundred and thirty eight) or $31.5 \%$ of the respondents who informed this. Subsequently, the data were followed by feeling anxious when traveling outside the house, where 137 (one hundred and thirty-seven) or $31.3 \%$ of the respondents admitted this entity. Meanwhile, 98 (ninety eight) or $22.4 \%$ of the Millennial generation stated that they were stricken with anxiety when they heard information related to Covid19. Such information was one related to the Covid-19 positive numbers, or precisely the information related to mortality rates caused by the Covid-19. Anxiety in the form of feelings of worry when traveling outside the house occupied the fifth form of anxiety, where there were at least 28 (twenty eight) respondents or around $6.4 \%$ of Millennials in Indonesia said that. Then, further questions are about how the Milllennial generation manages their anxiety and what kind of activities they do to eliminate the anxiety that strikes during the Covid-19 outbreak.

Table 6

Strategies to Avoid Anxiety over Covid-19

\begin{tabular}{lc}
\hline Reducing the Anxiety & $\mathrm{n}: 440$ \\
Maintain the immunity & $130(29.5)$ \\
Wash hands consistently & $84(19.1)$ \\
Work, study and worship from home & $184(41.8)$ \\
Avoid shaking hands or physical touching & $35(8)$ \\
Try not to touch face & $3(0.7)$ \\
Buying masks, basic food and other items & $2(0.5)$ \\
Keep shaking hands with cultural reasons & $2(0.5)$ \\
\hline
\end{tabular}




\section{Journal of Educational, Health and Community Psychology \\ Vol I0, No 3, 202I E-ISSN 2460-8467}

Wanto,

Jalwis.

The most dominant method used by Millennials to reduce or minimize anxiety related to Covid-19 was by consistently working, studying and worshiping from home. At least, 184 (one hundred and eighty four) or around $41.8 \%$ of the respondents said this entity. Then, corresponding to 'maintaining immunity', there were at least 130 (one hundred and thirty) or $29.5 \%$ of the respondents who informed this. Meanwhile, buying masks and basic needs and still shaking hands for cultural reasons were the lowest activities undertaken by the Millennial generation in Indonesia. Both were only done by 2 (two) or around $0.5 \%$ of the respondents who informed and did those entities. From this empirical fact, it is necessary to test the hypothesis: "Is there a significant influence of the Covid-19 pandemic (e.g. Millennial generation's knowledge) on social anxiety among Millennials in Indonesia." This hypothesis is built on the assumption that social anxiety is not taken for granted. But it is stimulated by complex co-factors (Han et al., 2019). One of the factors as such is the Covid-19 pandemic. Thus, it can be believed that the Covid-19 pandemic ( $\mathrm{X}$ variable) is determinant with social anxiety ( $\mathrm{Y}$ variable) experienced by the Millennial generation in Indonesia.

There are several empirical conditions that can be analyzed by referring to table 7 (correlation summary among variables), namely: First, the correlation value between the Covid-19 pandemic (e.g. perception and understanding of corona virus) and social anxiety is $41.7 \%$. The magnitude of the influence of the Covid-19 pandemic variable on social anxiety in Millennials is $17.4 \%$. The meaning of the foregoing is that $82.6 \%$ of social anxiety during the Covid-19 pandemic can also be influenced by other co-factors. Second, the significant influence of Covid-19 pandemic variable on social anxiety in Millennials in Indonesia is shown by the calculated $F$ value of 27,633 with a probability value of $0,000<0.05$, which means that this regression model can be used to predict the social anxiety variable. Third, value $t$ is 5257 with the significance of $0.000>0.05$. It conclusively says that there is a significant effect of the Covid-1 9 pandemic variable on social anxiety at Millennial generation in Indonesia. Then, the following question is "how is this statistical information interpreted theoretically?" At least there are several categories of theoretical explanations for statistical information having been presented. They extend to: First, a theory that explains that social anxiety can be stimulated by panic in responding to situations; and Second, the theory that explains that social anxiety is actually a psychological disorder when dealing 
with new situations. Both of these categories can and are believed to be the foundation in interpreting the statistical information that has been described.

Table 7.

Correlation Summary among Variables

\begin{tabular}{ll}
\hline Model Summary & \\
Correlation coefficient (R) & $0.4 I 7$ \\
R Square & 0.174 \\
Annova & \\
F Values & 27.633 \\
Significant & 0,000 \\
Coefficient & \\
t values & 5,257 \\
Significant & 0,000 \\
\hline Notes: $\mathrm{n}=|33, p<0.05, \mathrm{t}\rangle$ table $(5.257>1.97824)$ &
\end{tabular}

\section{Discussion}

The thesis that can be offered after interpreting previous statistical information is: "Social anxiety in the Millennial generation in Indonesia is caused by two things, namely by fear of social situations and efforts to avoid social situations that create a sense of being threatened." Anxiety in any form, including social anxiety is a natural response of humans when facing or being under threat. This can be felt through thoughts, feelings, and physical sensations (Women's Health Services, 2008). Likewise, social anxiety can be experienced by anyone, including the Millennial generation. The situation is the most determinant factor triggering social anxiety. The situation in question is a social situation that raises the feeling of being threatened by the Millennial generation (Heeren \& McNally, 2016). In this situation, social anxiety is a syndrome commonly felt by anyone, especially those trapped in social situations that threaten safety and are full of uncertainty (Kessler, Berglund, Demler, Jin, Merikangas, \& Walters, 2005). 
Social anxiety is characterized by intense fear, thus giving rise to actions to avoid social interaction (Hayward, Wilson, Lagle, Kraemer, Killen, \& Taylor, 2008). This can be identified empirically from the behavior of Millennials in Indonesia, when the Covid-19 outbreak, they tried to avoid making social contact involving physical interaction. Because it is believed that the transmission of the Covid-19 virus, one of which occurs due to physical contact or distance when communicating is less than I (one) meter from patients with Corona Virus. This is understandable because Millennials who are being hit by social anxiety will tend to or often digest information related to Covid-I 9 consistently, so that anxiety continues to persist in them (Bantin, Stevens, Gerlash, \& Hermann, 2016). Incorrect understanding of information will give rise to what is termed an attentional bias, or there is a bias in giving attention to information (Heimberg, R. G., Brozovich, F. A., \& Rapee, 2010). This condition will make social anxiety even stronger in a person, including the Millennials who are facing the Covid-19 pandemic.

Empirically, avoiding social interaction is considered the best way to reduce social anxiety (Mowrer, 1960). In conjunction with the Covid-19 pandemic, avoiding for the sake of reducing social fears and anxiety which arises is also interpreted as the procedure for breaking the chain of the spread of Covid19. In the other meaning, it is also to reduce the fear that grows in the Millennial generation when receiving information related to the Covid-19 pandemic. Despite the social anxiety experienced by Millennials in Indonesia, it does not reach the level of panic attacks (PAs), which are marked by intense fears (Versella et al., 2016). However, this social anxiety, of course, degrades the quality of social relations and the productivity of Millennials in Indonesia. In addition, the fear experienced by Millennials makes them avoid social interactions that involve physical contact and communication that is defined as unsafe from Covid-19 transmission. For example, they avoid using public transportation services, shaking hands, and being in crowded places. The reason, of course, is fear and anticipation of getting corona Virus infection.

It could be understood that anxiety, panic, and fear when being in crowded places as experienced by Millennials in Indonesia refer to a consequence of the widespread social anxiety because panic itself is part of and often arises with social anxiety (Barlow, \& Durand, 1995; Heimberg, Brozovich, \& Rapee, 2010). Individuals with social anxiety often experience panic. This is not due to genetic factors, but 
rather caused by the social situations they face. Finally, in this condition the individuals prefer to avoid social interaction (Jack, Heimberg, \& Mennin, 1999; Scott, Heimberg, \& Jack, 2000). This also happened to the Millennials in Indonesia when dealing with the Covid-19 pandemic. The new situation, being forced to leave behind the common routines, and undergoing almost completely new habits made the Millennials in Indonesia seized with anxiety. Not only were they afraid of the Covid-19 transmission, but they also feared of social evaluation if they violated Covid-19's handling procedures, leading them to be stigmatized with the status as the people under surveillance (PUS).

In a situation where Covid-19 pandemic is very worrying, all levels of society such as youth, adults, and parents are vulnerable to social anxiety and struck by panic. The indicators of this condition are the tendency to avoid and phobias when dealing with situations that are vulnerable to the spread of Covid19. Not only men, but women also experience social anxiety. At this time, social anxiety is followed by other mental disorders such as bad mood; and excessive fears (Rudaz et al., 2017). In general, social anxiety characterized by fear is negatively evaluated by the social environment, and this then makes an individual with the symptoms of social anxiety driven to try to avoid situations that make him have to interact with others (Rudaz et al., 2017). However, the social anxiety that arises caused by the Covid19 pandemic is slightly different. This anxiety is caused by not only a fear of being negatively perceived socially but also a fear when interacting with other individuals and this is even detrimental to him. Feelings in danger when interacting or being in crowded places are an active mental condition causing social anxiety among the Millennials in Indonesia when Covid-19 was endemic.

In the theory of "cognitive model of social anxiety", it can be understood that individuals with high social anxiety will tend to suffer from experiencing what is termed "in-situation or subtle safety disorder". In this situation, the individuals will tend to avoid eye contact when talking with others (Rudaz et al., 2017). In contrast to the social anxiety caused by the Covid-19 pandemic, this mental condition is accompanied by excessive fears of Covid-19 transmission. Not only is feeling threatened by Covid-19, but political, social, cultural and religious policies which are driving the new situation faced by Millennials in Indonesia also increase social anxiety among them. To name a few, such policies are such as learning from home and worship at home. This condition has limited the mobility of Millennials. In this situation, 
social anxiety coupled with fears and being threatened by the Covid-19 epidemic will always be experienced by Millennials in Indonesia, even intensely occurring while the Covid-19 pandemic is still ongoing. Conversely, if the Covid-19 pandemic really ends, social anxiety then decreases automatically.

\section{Conclusion}

This study has found that: "the social anxiety experienced by Millennials during the Covid-19 outbreak is a product of social situations. The foregoing is in light of that the relationship of the Covid-19 pandemic according to the perceptions and understanding of the Millennial generation in Indonesia and social anxiety is evident. The influence of the Covid-19 pandemic on social anxiety has even significantly folded." This thesis is supported by several empirical facts. First, the Millennial generation in Indonesia dominantly understands that the situation faced by Indonesia is very serious and should not be ignored. There are at least $89.3 \%$ of the respondents who inform this entity. Second, the social anxiety that is commonly experienced by Millennials in Indonesia is anxiety when being in crowd places. There are $31.5 \%$ of the respondents who expressed this entity. Third, generally the Millennial generation in Indonesia follows the government's policy in reducing the spread of Covid-19 through working, studying, and worship from home. This is shown by $41.8 \%$ of the respondents who agree with this policy. Finally, the relationship between the Covid-19 pandemic and social anxiety among Millennials in Indonesia is significant. This can be concluded from the obtained $F$ value of 27,633 with a significance level of 0,000 which means that it is smaller than 0.05 . Likewise, the obtained $t$ value is of 5.257 and it is greater than the value of $t$ table. In addition, it is strengthened by a correlation value of $41.7 \%$ which means that the relationship between the Covid-19 pandemic variable and the social anxiety variable in the Millennial generation in Indonesia is significantly evident.

\section{References}

Abdullah, I. (2020). Psychological trauma: Theory, research, practice, and policy COVID-19: Threat and Fear in Indonesia. American Psychological Association.

Ahmed, M. Z., Ahmed, O., Aibao, Z., Hanbin, S., Siyu, L., \& Ahmad, A. (2020). Epidemic of COVID-19 
in China and associated psychological problems. Asian Journal of Psychiatry, 5 I(April), 102092. https://doi.org//0.1016/j.ajp.2020.102092

Arkin, R. M., Appelman, A. J., \& Burger, J. M. (1980). Social anxiety, self-presentation, and the selfserving bias in causal attribution. Journal of Personality and Social Psychology, Vol. 38(I), 23-35.

Bal, R., de Graaff, B., van de Bovenkamp, H., \& Wallenburg, I. (2020). Practicing corona - towards a research agenda of health policies. Health Policy, 124(7), 67I-673. https://doi.org/10.1016/j.healthpol.2020.05.010

Bantin, T., Stevens, S., Gerlash, A. L., \& Hermann, C. (2016). What does the facial dot-probe task tell us about attentional processes in social anxiety? A systematic review. Journal of Behaviour Therapy and Experimental Psychiatry, 50, 40-51.

Barlow, H.D., \& Durand, V. M. (1995). Abnormal psychology. Brook/Cole Publishing Company.

Cai, W., Lian, B., Song, X., Hou, T., Deng, G., \& Li, H. (2020). A cross-sectional study on mental health among health care workers during the outbreak of corona virus disease 2019. Asian Journal of Psychiatry, 5 I (April), I02III. https://doi.org/I0.1016/j.ajp.2020.102III

Carleton, R. N., Collimore, K. C., McCabe, R. E., \& Antony, M. M. (20I I). Addressing revisions to the brief fear of negative evaluation scale: Measuring fear of negative evaluation across anxiety and mood disorders. Journal of Anxiety Disorders, 25, 822-828.

Carmassi, C., Foghi, C., Dell'Oste, V., Cordone, A., Bertelloni, C. A., Bui, E., \& Dell'Osso, L. (2020). PTSD symptoms in healthcare workers facing the three coronavirus outbreaks: What can we expect after the COVID-19 pandemic. Psychiatry Research, 292(July), II33I2. https://doi.org/https://doi.org/I0.1016/j.psychres.2020.1I33/2

Crozier, W. R., \& Alden, L. E. (2005). The essential handbook of social anxiety for clinicians. John Wiley \& Sons, Ltd.

D. M. Buss. (2005). The handbook of evolutionary psychology. John Wiley \& Sons Inc.

Dubey, S., Biswas, P., Ghosh, R., Chatterjee, S., Dubey, M. J., Chatterjee, S., Lahiri, D., \& Lavie, C. J. (2020). Psychosocial impact of COVID-19. Diabetes and Metabolic Syndrome: Clinical Research and Reviews, I4(5), 779-788. https://doi.org//0.1016/j.dsx.2020.05.035

Dumas, T. M., Ellis, W., \& Litt, D. M. (2020). What does adolescent substance use look like during the covid-19 pandemic? examining changes in frequency, social contexts, and pandemic-related predictors. Journal of Adolescent Health. https://doi.org/I0.1016/j.jadohealth.2020.06.018 
Elsantil, Y., \& Hamza, E. A. (2019). The impact of self-conscious emotions on willingness to pay for sustainable products. Humanities and Social Sciences Reviews, 7(2), 77-90. https://doi.org//0.185I0/hssr.2019.729

Ferreira, C. M., \& Serpa, S. (2018). Informed consent in social sciences research: Ethical challenges. International Journal of Social Science Studies, 6(5), 13. https://doi.org/I0.1 I I I4/ijsss.v6i5.3 106

Friana, H. (2020). WHO umumkan corona COVID-I9 sebagai pandemi. Tirto.

Gaiser, T., \& Schreiner, A. (2012). A guide to conducting online research. In A Guide to Conducting Online Research. Sage Publications. https://doi.org// 0.4135/9780857029003

Gilbert, P. (200I). Evolution and social anxiety: The role of attraction, social competition, and social hierarchies. Social Anxiety Disorder, 24(4), 723-75I.

Hamdan Mansour, A., Al Shibi, A. N., Khalifeh, A. H., \& Hamdan Mansour, L. A. (2020). Health-care workers' knowledge and management skills of psychosocial and mental health needs and priorities of individuals with COVID-19. Mental Health and Social Inclusion. https://doi.org//0.1 108/MHSI-042020-0022

Han, S. H., Kim, K. T., Ryu, H. U., Lee, S. A., Cho, Y. J., Kim, J. H., Kang, K. W., Shin, D. J., Lee, G. H., Hwang, K. J., Kim, Y. S., Kim, J. Bin, Kim, J. E., Lee, S. Y., \& Seo, J. G. (2019). Factors associated with social anxiety in South Korean adults with epilepsy. Epilepsy and Behavior, 101, 106569. https://doi.org//0.1016/j.yebeh.2019.106569

Hayward, C., Wilson, K. A., Lagle, K., Kraemer, H. C., Killen, J. D., \& Taylor, C. B. (2008). The developmental psychopathology of social anxiety in adolescents. Depression \& Anxiety, 25, 200 206.

Heeren, A., \& McNally, R. J. (2016). An integrative network approach to social anxiety disorder: The complex dynamic interplay among attentional bias for threat, attentional control, and symptoms. Journal of Anxiety Disorders, 42, 95-104. https://doi.org//0.1016/j.janxdis.2016.06.009

Heimberg, R. G., Brozovich, F. A., \& Rapee, R. M. (2010). A cognitive model of social anxiety disorder: update and extension. In: S. G. Hofmann, \& P. M. DiBartolo (Eds.), Social anxiety: clinical, developmental, and social perspectives (2nd ed). Academic Press.

Hezel, D. M., \& McNally, R. J. (20I4). Theory of mind impairments in social anxiety disorder. Behavior Therapy, 45, 530-540.

Islam, M. A., Barna, S. D., Raihan, H., Khan, M. N. A., \& Hossain, M. T. (2020). Depression and anxiety among university students during the COVID-19 pandemic in Bangladesh: A web-based cross- 


\section{Journal of Educational, Health and Community Psychology \\ Vol I0, No 3, 202 I E-ISSN 2460-8467}

Wanto,

Jalwis.

sectional survey. PLOS ONE, 15(8), e0238I62. https://doi.org/I0.137//journal.pone.0238I62

Jack, M. S., Heimberg, R. G., \& Mennin, D. S. (1999). Situational panic attacks: Impact on distress and impairment among patients with social phobia. Depression and Anxiety. Depression and Anxiety, Vol. I0, II 2-II8. https://doi.org/https://doi.org//0.1002/(SICl)I520- 6394(I999)|0:3<I I2::AIDDA4>3.0.CO;2-U

Karasewich, T. A., \& Kuhlmeier, V. A. (2020). Trait social anxiety as a conditional adaptation: A developmental and evolutionary framework. Developmental Review, 55(September 2019), 100886. https://doi.org/10.1016/j.dr.2019.100886

Kearney, C. A. (2005). Social anxiety and social phobia in youth characteristics, assessment, and psychological treatment. Springer.

Keliat, B. A., Triana, R., \& Sulistiowati, N. M. D. (2019). The relationship between self-esteem, family relationships and social support as the protective factors and adolescent mental health. Humanities and Social Sciences Reviews, 7(I), 4I-47. https://doi.org/I0.185I0/hssr.2019.7I5

Kessler, R. C., Berglund, P., Demler, O., Jin, R., Merikangas, K. R., \& Walters, E. E. (2005). Lifetime prevalence and age-of-onset distributions of DSM-IV disorders in the national comorbidity survey replication. Archives of General Psychiatry, 62, 593-602.

Kumar, A., \& Somani, A. (2020). Dealing with corona virus anxiety and OCD. Asian Journal of Psychiatry, 5I, 102053. https://doi.org//0.1016/j.ajp.2020.102053

Leary, M. R., \& Kowalski, R. M. (1995). Social anxiety. The Guilford Press.

Leibenluft, E., Pine, D. S., Jarcho, J. M., Villarosa-Hurlocker, M. C., Madson, M. B., Arai, H., Kurihara, M., Yasutaka, T., Pitcho-prelorentzos, S., Heckel, C., Ring, L., Moguel-cobos, G., Saldivar, C., Goslar, P. W., Shill, H. A., Fredrick, J. W., Luebbe, A. M., Han, S., Tae, K., ... Seo, J. (2020). Social anxiety and age are associated with neural response to social evaluation during adolescence. Addictive Behaviors, Vol. 42(April), 106284. https://doi.org//0.1016/j.den.2020.100768

Lestari, E. S. (20I2). Hubungan Kecemasan sosial dan kematangan emosis dengan kematangan seksual remaja SMP di kabupaten Bantul, Yogyakarta. Psikopedagogia, I I I), I45-I59.

Li, Z., Ge, J., Yang, M., Feng, J., Qiao, M., Jiang, R., Bi, J., Zhan, G., Xu, X., Wang, L., Zhou, Q., Zhou, C., Pan, Y., Liu, S., Zhang, H., Yang, J., Zhu, B., Hu, Y., Hashimoto, K., ... Yang, C. (2020). Vicarious traumatization in the general public, members, and non-members of medical teams aiding in COVID-19 control. Brain, Behavior, and Immunity, March, 0-I. https://doi.org//0.1016/j.bbi.2020.03.007 
Liu, N., Zhang, F., Wei, C., Jia, Y., Shang, Z., Sun, L., Wu, L., Sun, Z., Zhou, Y., Wang, Y., \& Liu, W. (2020). Prevalence and predictors of PTSS during COVID-19 outbreak in China hardest-hit areas: Gender differences matter. Psychiatry Research, 287(March), II292I. https://doi.org/I0.1016/j.psychres.2020.1 I292I

McNeil, D. W., Porter, C. A., Zvolensky, M. J., Chaney, J. M., \& Kee, M. (2000). Assessment of culturally related anxiety in American Indians and Alaska Natives. Behavior Therapy, 3 I, 30 I-325.

Mehrollahia, T., Nora, M. M., Danaeeb, M., \& Trenamanc, B. (2019). How scientific production positively affect social psychology intervention? A bibliometric analysis on the science of wellbeing. Humanities and Social Sciences Reviews, 7(5), 327-339. https://doi.org//0.18510/hssr.2019.7538

Mertens, G., Gerritsen, L., Duijndam, S., Salemink, E., \& Engelhard, I. M. (2020). Fear of the coronavirus (COVID-19): Predictors in an online study conducted in March 2020. Journal of Anxiety Disorders, 74(March). https://doi.org/10.1016/j.janxdis.2020.102258

Mohamad, Z., Husain, Z., Talib, J. A., Yusof, R. A. M., Ramley, F., Dagang, M. M., Raji, N. A. A., \& Noor, M. M. (2019). The effectiveness of art therapy module on the well-being of single mothers. Humanities and Social Sciences Reviews, 7(I), 44I-449. https://doi.org/I0.185I0/hssr.2019.7I50

Mowrer, O. H. (1960). Learning theory and behavior. Wiley.

Musmade, P., Nijhawan, L., Udupa, N., Bairy, K., Bhat, K., Janodia, M., \& Muddukrishna, B. (2013). Informed consent: Issues and challenges. Journal of Advanced Pharmaceutical Technology \& Research, 4(3), I34. https://doi.org/ 10.4103/223 I-4040.I I6779

Nunnally, J. (1960). The place of statistics in Psychology. Educational and Psychological Measurement, 20(4), 64 I-650. https://doi.org// 0.1 I77/00 I 31644600200040 I

Olapegba, P. O., lorfa, S. K., Kolawole, S. O., Oguntayo, R., Gandi, J. C., Ottu, I. F. A., \& Ayandele, O. (2020). Survey data of Covid-19-related knowledge, risk perceptions and precautionary behavior among Nigerians. Data in Brief, 30, 105685. https://doi.org//0.1016/j.dib.2020.105685

Oosterhoff, B., Palmer, C. A., Wilson, J., \& Shook, N. (2020). Adolescents' motivations to engage in social distancing during the COVID-19 pandemic: Associations with mental and social health. Journal of Adolescent Health. https://doi.org// 0.1016/j.jadohealth.2020.05.004

Panagiotidis, T. (20/4). Testing the assumption of linearity testing the assumption of linearity the assumption of linearity is tested using five statistical tests for the US and the Canadian. Economics Bulletin, 3(29), 123-135. 
Patrick Galey. (2020, April). Covid 19 to have "profound" mental health fallout. The Jakarta Post.

Perrin, P. C., McCabe, O. L., Everly, G. S. \& Links, J. M. (2009). Preparing for an influenza pandemic: Mental health considerations. Prehospital and Disaster Medicine, Vol. 24(3), 223-230.

Reese, G., Hamann, K. R. S., Heidbreder, L. M., Loy, L. S., Menzel, C., Neubert, S., Tröger, J., \& Wullenkord, M. C. (2020). SARS-Cov-2 and environmental protection: A collective psychology agenda for environmental psychology research. Journal of Environmental Psychology, 70, 101444. https://doi.org//0.1016/j.jenvp.2020.101444

Rubin, G. J. \& Wessely, S. (2020). The psychological effects of quarantining a city. British Medical Journal, Vol. 368(3|3). https://doi.org/https://doi.org//0.1/36/bmj.m3/3

Rudaz, M., Ledermann, T., Margraf, J., Becker, E. S., \& Craske, M. G. (2017). The moderating role of avoidance behavior on anxiety over time: Is there a difference between social anxiety disorder and specific phobia? PLoS ONE, 12(7), I-14. https://doi.org/I 0.137//journal.pone.0180298

S. G. Hoffman, \& P. M. D. (2010). Social anxiety: Clinical, developmental, and social perspectives (\& P. M. D. S. G. Hoffman (ed.)). Academic Press.

Saraçlı, S., Yılmaz, V., \& Doğan, i. (2009). Simple linear regression techniques in measurement error Models. Anadolu University Journal of Science and Technology, I0(April 2008), 335-342.

Saylor, R.D., Edgerton, E.S. and Hartsell, B. E. (2006). Linear regression techniques for use in the EC tracer method of secondary organic aerosol estimation. Atmospheric Environment, 40, 7546-7556.

Scott, E. L., Heimberg, R. G., \& Jack, M. S. (2000). Anxiety sensitivity in social phobia: Comparison between social phobics with and without panic attacks. Depression and Anxiety, Vol. 12, 189-192. https://doi.org/https://doi.org//0.1002//520- 6394(2000) I2:4<|89::AID-DA I>3.0.CO;2-X

Sergeeva, M. G., Bondarenko, N. G., Shebzuhova, T. A., Vartumyan, A. A., Shuisky, A. S., \& Mazurenko, A. P. (2019). Legal culture formation of a future specialist. Humanities and Social Sciences Reviews, 7(4), 13-19. https://doi.org/10.18510/hssr.2019.742

Shalit, H. (20I2). Using OLS to test for normality. Statistics and probability letters, 82(II), 2050-2058. https://doi.org//0.1016/j.spl.2012.07.004

Shiina, A., Niitsu, T., Kobori, O., Idemoto, K., Hashimoto, T., Sasaki, T., Igarashi, Y., Shimizu, E., Nakazato, M., Hashimoto, K., \& lyo, M. (2020). Relationship between perception and anxiety about covid-19 infection and risk behaviors for spreading infection: Preliminary report of a national survey in Japan. SSRN Electronic Journal, I00 I0I. https://doi.org/I0.2I 39/ssrn.3582777 
Singh, S., Bhutani, S., \& Fatima, H. (2020). Surviving the stigma: lessons learnt for the prevention of COVID-19 stigma and its mental health impact. Mental Health and Social Inclusion. https://doi.org// 0.1 I08/MHSI-05-2020-0030

Situmorang, N. Z. (2019). The correlation of self-efficacy and peer support towards anxiety preceding final examinations faced by 9th graders in Yogyakarta. Humanities and Social Sciences Reviews, 7(3), 169-175. https://doi.org//0.18510/hssr.2019.7326

Smith, A. P. (2013). Twenty-five years of research on the behavioural malaise associated with influenza and the common cold. Psychoneuroendocrinology, 38(6), 744-75I. https://doi.org/I0.1016/j.psyneuen.2012.09.002

Sundarasen, S., Chinna, K., Kamaludin, K., Nurunnabi, M., Baloch, G. M., Khoshaim, H. B., Hossain, S. F. A., \& Sukayt, A. (2020). Psychological impact of COVID-19 and lockdown among university students in Malaysia: Implications and policy recommendations. International Journal of Environmental Research and Public Health, I7(17), 6206. https://doi.org/I0.3390/ijerph17176206

Syahir, A. (2020). Analisis perubahan psikososial: depresi dan ansietas selama pandemi Covid-I 9 pada kalangan pelajar. JIMKI, 8(3), I74-188.

Tian, F., Li, H., Tian, S., Yang, J., Shao, J., \& Tian, C. (2020). Psychological symptoms of ordinary Chinese citizens based on SCL-90 during the level I emergency response to COVID-19. Psychiatry Research, 288(April), I I 2992. https://doi.org/ 10.1016/j.psychres.2020.I I 2992

Usher, K., Durkin, J., \& Bhullar, N. (2020). The COVID-19 pandemic and mental health impacts. International Journal of Mental Health Nursing. https://doi.org/I0.I I I I/inm. 12726

Varalakshmi, R., \& Swetha, R. (2020). Covid- 19 lock down: People psychology due to law enforcement. Asian Journal of Psychiatry, 5I, 102102. https://doi.org//0.1016/j.ajp.2020.102102

Versella, M. V., Potter, C. M., \& Heimberg, R. G. (2016). Socially-relevant panic symptoms in social anxiety disorder. Journal of Experimental Psychopathology, 7(4), 564-576. https://doi.org//0.5 I27/jep.0564I6

Wind, T. R., Rijkeboer, M., Andersson, G., \& Riper, H. (2020). The Covid-19 pandemic: The 'black swan' for mental health care and a turning point for e-health. Internet Interventions, 20(March), I003 I7. https://doi.org/10.1016/j.invent.2020.100317

Womens Health Services, W. (2008). Anxiety and panic attacks - Nutrition.

Xiang, Y. T., Li, W., Zhang, Q., Jin, Y., Rao, W. W., Zeng, L. N., Lok, G. K. I., Chow, I. H. I., Cheung, T., \& Hall, B. J. (2020). Timely research papers about COVID-I9 in China. The Lancet, 395(I0225), 
684-685. https://doi.org//0.10I6/S0I40-6736(20)30375-5

Zhu, B., Zheng, X., Liu, H., Li, J., \& Wang, P. (2020). Analysis of spatiotemporal characteristics of big data on social media sentiment with COVID-19 epidemic topics. Chaos, Solitons and Fractals, 140, I I0I23. https://doi.org/I0.1016/j.chaos.2020.1 I0123 